\title{
SOSIAALITYÖN PSYKOSOSIAALINEN ASIANTUNTIJUUS NUORISOPSYKIATRIAN MONIAMMATILLISEN TYÖYHTEISÖN MÄÄRITTELMÄNÄ
}

Miina Arajärvi: YTM, sosiaalityön väitöskirjatutkija, Itä-Suomen yliopisto

Kaarina Mönkkönen: YTT, dosentti, yliopistonlebtori, Itä-Suomen yliopisto

Taru Kekoni: YTT, yliopistonlehtori, Itä-Suomen yliopisto

Timo Toikko: YTT, professori, Itä-Suomen yliopisto

miinak@ueffi; kaarina.monk.konen@ueffi; taru.kekoni@ueffi; timo.toikko@uef.fi

Janus vol. 28 (4) 2020, 357-373

\section{Tiivistelmä}

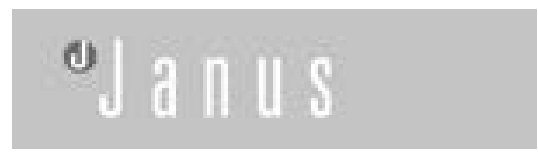

$\boldsymbol{y}$

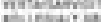

Sosiaalityöntekijät työskentelevät nuorisopsykiatriassa erityistyöntekijöinä tuoden sosiaalista näkökulmaa moniammatilliseen vuoropuheluun. Nuorisopsykiatriassa on viime vuosina kehitetty hoitomalleja. Samalla erityistyöntekijöiden työnkuvaa on pyritty vahvistamaan. Artikkelissa sosiaalityön psykososiaalisen asiantuntijuuden jäsentymistä tarkastellaan nuorisopsykiatrian avohoidon monialaisessa ja muuttuneessa toimintaympäristössä. Tutkimuksen aineisto koostuu nuorisopsykiatrian ammattilaisille järjestetyistä fokusryhmähaastatteluista. Nuorisopsykiatriassa psykososiaalinen sosiaalityö jäsennetään kaksoisroolina, joka koostuu nuoren sosiaalisen toimintakyvyn ja perheen kokonaistilanteen arvioimisesta ja palveluverkoston koordinoinnista sekä terapeuttisesta työstä. Ammattiryhmien haastatteluissa korostui yhteisesti näkemys siitä, että lähtökohtana sosiaalityöntekijän asiantuntijuudelle nuorisopsykiatriassa on ymmärrys psyykkisten oireiden vaikutuksesta nuoren sosiaaliseen toimintakykyyn.

\section{JOHDANTO}

Terveydenhuollossa tehtävää sosiaalityötä kuvataan yleensä psykososiaaliseksi sosiaalityöksi. Psykososiaalisella tarkoitetaan ihmisten kokemuksia, jotka muodostuvat yksilön psykologisten kykyjen ja sosiaalisen ympäristön vuorovaikutuksessa (Adams ym. 2009). Psykososiaalisen sosiaalityön perustana on ihmisen holistisuus (mm. Berner ym. 1988; Venkat 2014; Weckroth 2007; Granfelt 1993),joka nuorisopsykiatriassa kytkeytyy nuoren kokonaisvaltaisen hyvinvoinnin ja toimintaympäristön, kuten kasvuolosuhteiden, tarkasteluun. Nuorisopsykiatrisessa avohoidossa sosiaalityöntekijät työskentelevät tiiviisti muiden ammattiryhmien kanssa tavoit- teenaan nuoren kokonaisvaltaisen hyvinvoinnin tukeminen.

Tutkimus on toteutettu nuorisopsykiatrian avohoidossa Helsingin ja Uudenmaan sairaanhoitopiirissä (HUS). HUS:n nuorisopsykiatrian avohoidon asiakkaat ovat iältään 13-17-vuotiaita. Nuorisopsykiatriassa työskentelee eri tieteenalojen ammattilaisia, kuten lääkäreitä, psykologeja, sairaanhoitajia, sosiaalityöntekijöitä ja toimintaterapeutteja. Nuorisopsykiatrian sosiaalityöntekijät ovat erityistyöntekijöitä, jotka tuovat sosiaalityön näkökulmaa moniammatilliseen keskusteluun. Moniammatillisessa hoitoryhmätyöskentelyssä jokaisella ammattilaisella on oma roolinsa, joka perustuu kunkin omaan ammatti-identiteettiin ja koulutustaus- 
taan (Adams ym. 2006; D'Amour ym. 2005). Artikkelissa tarkastellaan, miten nuorisopsykiatrian eri ammattiryhmät määrittelevät sosiaalityön asiantuntijuutta moniammatillisessa työyhteisössä.

Nuorisopsykiatrian tavoitteena on tuottaa tehokkaita ja laadukkaita palveluita nuoruusikäisten potilaiden parhaaksi. HUS nuorisopsykiatriassa on viime vuosina uudistettu hoitoja ja hoitoryhmien rakennetta siirtyen entistä fokusoidumpiin hoitomalleihin. Fokusoiduissa hoidoissa useimmiten sairaanhoitaja tai psykologi vastaa nuoren hoidon toteutuksen kokonaisuudesta. Aikaisemmin työskentely on perustunut moniammatilliseen työparityöskentelyyn, jossa sosiaalityöntekijä on toiminut perhe- ja verkostotyöntekijän roolissa ja sairaanhoitaja on hoitanut nuorta. Toimintatavat ja hoitomuodot voivat vaihdella eri poliklinikoilla riippuen työtilanteesta, työkiireestä ja työn luonteesta.

Nykytilanteen taustalla ovat hoidon kehittymisen lisäksi palvelujärjestelmän muutokset, sekä ammattilaisten resurssien käyttöön ja erikoissairaanhoidon tuotteistamiseen kohdistetut tehokkuusvaatimukset. Muuttuva palvelujärjestelmä ja uudistukset aiheuttavat väistämättä muutoksia ammattilaisten työn sisältöjen määrittelyyn sekä työnjakoon (THL-Raportti 2016). Asiakkaiden palveluiden tarve, laatuun kohdistuvat odotukset ja niukkenevat resurssit edellyttävät uudenlaisia, jopa radikaaleja toiminnan muutoksia (Stenvall ym. 2012, 40), jotka näkyvät erikoissairaanhoidossa muun muassa työn tehostamisena ja fokusoitujen hoitomallien käyttöönottona. Muutosten yhteydessä erityistyöntekijöiden, kuten sosiaalityöntekijöiden, työnkuvaa on pyritty jäsentämään uudelleen ja vahvistamaan sitä osana moniammatillista yhteistyötä. Uudistuksen yhteydessä tai sen jälkeen sosiaalityön asiantuntijuuden jäsentymisestä nuorisopsykiatriassa ei ole kuitenkaan tehty empiiristä tutkimusta.

Tämän tutkimuksen avulla saadaan empiiristä tietoa nuorisopsykiatrian sosiaalityön asiantuntijuuden jäsentymisestä moniammatillisen työryhmän määrittelemänä. Tietoa voidaan hyödyntää, kun sosiaalityön työnkuvaa määritellään erikoissairaanhoidossa, mutta myös palvelujärjestelmätason yhteistyössä. Tutkimuksen aineistona on HYKS:n nuorisopsykiatrian avohoidon (HYKS-sairaanhoitoalue kuuluu HUS-alueeseen) ammattilaisille järjestetyt ammattiryhmäkohtaiset fokusryhmähaastattelut, jotka toteutettiin vuonna 2018.

\section{SOSIAALITYÖ MONIAMMATILLISESSA TYÖYHTEISÖSSÄ MIELENTERVEYSPALVELUISSA}

Mielenterveyden ja sosiaalisten tekijöiden välistä suhdetta määrittää sen kaksisuuntainen luonne, missä sosiaaliset ongelmat usein lisäävät mielenterveysongelmien todennäköisyyttä ja psyykkiset ongelmat puolestaan kapeuttavat yhteiskunnallista osallisuutta (Frankenhaueser 2014, 67; Leinonen 2018, 136). Tässä tutkimuksessa sosiaalisen käsitettä ja sosiaalisia ongelmia tarkastellaan nuoren sosiaalisen toimintakyvyn näkökulmasta. Sosiaalisen toimintakyvyn käsitteelle ei löydy yhtä selkeää määrittelyä (vrt. kuitenkin WHO:n ICF-luokitus 2004). 
Terveyden ja hyvinvoinnin laitoksen (2019) määritelmän mukaan sosiaalisen toimintakyvyn kokonaisuus muodostuu yksilön, sosiaalisen verkoston, ympäristön, yhteisön ja yhteiskunnan välisissä dynaamisissa vuorovaikutussuhteissa. Nuorten sosiaalisen toimintakyvyn määrää ja laatua on kansainvälisesti tutkittu muun muassa mittaamalla nuorten stressiä, ihmissuhteita, sosiaalisia taitoja, sosiaalisia tilanteita, perhesuhteita ja kaveriverkoston laajuutta (Bertz ym. 2005, 186). Psykososiaalinen sosiaalityö lasten ja nuorten klinikkatyössä keskittyy lapsen ja nuoren sosiaalisen toimintakyvyn kartoittamiseen ja arvioimiseen (mm. Gunningham ym. 2008, 350-351).

Nuorisopsykiatrian potilailla on usein psyykkisten oireiden lisäksi sosiaalisia ongelmia, kuten vuorovaikutushaasteita perhesuhteissa tai koulunkäyntivaikeuksia. Sosiaalityön osuus nuorten moniammatillisen hoidon suunnittelussa ja toteutuksessa keskittyy nuoren sosiaalisen toimintakyvyn ja toimintaympäristön, kuten koulunkäynnin ja perhetilanteen, tarkasteluun. Bland $(2014,4)$ toteaakin, että sosiaalityön asiantuntijuus nuorten moniammatillisessa mielenterveystyössä liittyy vahvasti sosiaalisen toimintaympäristön ja ihmissuhteiden huomioimiseen sekä oikeudenmukaisuuden kysymyksiin. Psykologien työskentelyn lähtökohtana puolestaan ovat usein nuorten kognitiiviset kyvykkyydet. Hoitajat lähestyvät nuoren oireilua hoitotieteen näkökulmasta ja lääkäri on pääsääntöisesti vastuussa hoitosuunnitelman laadinnasta ja lääkehoidon toteutuksesta. Ammattiroolit osin määrittävät hoidon näkökulmaa, mutta yhteisessä prosessissa kehittyy myös yhteinen tarkastelutapa
(Mönkkönen ym. 2019). Esimerkiksi psykiatrisessa moniammatillisessa hoidon arviointipalaverissa yhteistä työskentelyä ohjaavat hoidontarpeen, mielenterveyden, huolen ja tulevaisuuden tulkintakehykset. Nämä tulkintakehykset voivat vaihdella sekä asiakkaan että ammattilaisten puheenvuoroissa. (Pehkonen ym. 2019.)

Terveydenhuollon moniammatillisessa yhteistyössä jokaisella ammattilaisella on oma roolinsa. Yhteistyö muodostaa epävirallisia normeja siitä mitä töitä voidaan jakaa ja missä tehtävissä roolirajoja ei ylitetä. Esimerkiksi somaattiset hoitotoimenpiteet, kuten verenpaineen mittaus, kuuluvat pääsänntöisesti hoitotyöntekijöille. Moniammatillisessa työyhteisössä ammattilaisten näkemykset toistensa rooleista ja asiantuntijuudesta voivat vaihdella (Ambrose-Miller ym. 2016). Oman asiantuntijuuden rajoista ja näkemyksistä voi olla vaikea pitää kiinni tilanteissa, joissa moniammatillisen työryhmän näkemykset eivät ole yhdenmukaiset. Ammattilaisten kesken näkemyseroja voi syntyä esimerkiksi tilanteen määrittämiseen tai siihen puuttumiseen liittyvissä kysymyksissä. Myös professioiden väliset valta- ja vastuusuhteet tunnistetaan yleensä yhteistyöhön liittyviksi ongelmiksi. Moniammatillisessa yhteistyössä sosiaalityöntekijä vastaa potilaan sosiaalisen hyvinvoinnin turvaamisesta ja sen huomioimisesta kokonaisuutta arvioitaessa. (mm. Frost 2005, 188.)

Moniammatillisen työskentelyn näkökulmasta on tärkeää tunnistaa eri alojen ammattilaisten roolit osana kokonaisuutta. Silloin, kun ryhmät määrittelevät omaa perustehtäväänsä ne tulevat sulkeneeksi pois tehtäviä, joiden 
ei nähdä kuuluvan omaan työnkuvaan tai rooliin. (Kekoni ym. 2019.) Myös yhteistyön merkitys voidaan hahmottaa monin eri tavoin ja tällä hahmottamistavalla on väistämättä yhteys siihen, miten toimitaan (Rydenfält ym. 2018). Tässä tutkimuksessa tarkastelemme nuorisopsykiatrian eri ammattiryhmien tulkintoja sosiaalityön asiantuntijuudesta moniammatillisessa yhteistyössä.

Nuorisopsykiatrian moniammatillinen yhteistyö nivoo yhteen ammattilaisten näkemykset potilaan biologisten, psykologisten ja sosiaalisten tasojen välisestä suhteesta. Biopsykososiaalinen malli tarjoaa tähän yhden, eri ammattikuntia yhdistävän kehyksen. Mallissa ihmisen terveyttä ja monialaista yhteistyötä tarkastellaan monitasoisena rakennelmana. Tasot koostuvat biologisesta, psykologisesta ja sosiaalisesta tasosta, jotka ovat dynaamisessa vuorovaikutuksessa keskenään (Kerätär ym. 2014; Engel 1977). Biopsykososiaalisessa mallissa biologian nähdään yhdistyvän kiinteästi ympäristöön ja sosiaalisiin tekijöihin (Engel 1980). Parhaimmillaan moniammatillinen yhteistyö ja mallin tarjoama yhdistävä kehys palvelee nuoren kokonaisvaltaisen hyvinvoinnin ja kuntoutumisen edistymistä. Tässä tutkimuksessa biopsykososiaalinen malli nähdään moniammatillista yhteistyötä jäsentävänä kehyksenä nuorisopsykiatriassa. Se ei kuitenkaan toimi varsinaisena tutkimuksen teoreettista päättelyä ohjaavana viitekehyksenä.

\section{TutKimusasetelma Ja} AINEISTON ANALYYSI

Tutkimuksen tehtävänä on tarkastella, millaisena nuorisopsykiatrian avohoi- don sosiaalityön asiantuntijuus jäsentyy osana moniammatillista yhteistyötä. Sosiaalityön asiantuntijuuden jäsentymistä tarkastellaan nuorisopsykiatriassa työskentelevien ammattilaisten määrittelemänä. Tutkimusaineisto koostuu viidestä ammattiryhmäkohtaisesta fokusryhmähaastattelusta, jotka toteutettiin vuoden 2018 aikana HYKS nuorisopsykiatrian avohoidon työntekijöille. Tutkimuksen aineiston hankinta, perehtyminen siihen sekä analysointi nivoutuivat prosessissa toisiinsa.

Haastateltavia lähestyttiin sähköpostilla jokaisen ammattiryhmän esimiehen kautta. Tutkimukseen osallistui ammattilaisia eri puolilta HUS:ia ja erilaisista nuorisopsykiatrian poliklinikoista, kuten hoitopoliklinikoilta ja tutkimus- ja arviointiyksiköistä. Sosiaalityö saattaa näyttäytyä erilaisena sen mukaan, mitä HUS:n organisaation osaa tarkastellaan. Jos yksikössä työskentelee vain yksi sosiaalityöntekijä, sosiaalityö saattaa yksilöityä liiaksi tietyn henkilön persoonallisella otteellaan tekemäksi työksi, vaikka työtä ohjaavat yhteiset linjaukset.

Fokusryhmähaastatteluihin osallistui kuusi lääkäriä, seitsemän psykologia, kolme toimintaterapeuttia, neljä sosiaalityöntekijää ja neljä sairaanhoitajaa. Kaikilla lääkäreillä, sairaanhoitajilla, toimintaterapeuteilla ja psykologeilla oli kokemusta yhteistyöstä sosiaalityöntekijän kanssa. Fokusryhmähaastattelut pidetään usein homogeenisille ryhmille, joilla on kokemuksia samoista asioista (Liamputtong 2011). Aineistonkeruumenetelmäksi valittiin fokusryhmähaastattelut (ks. Neergaard \& Leitch 2015), koska niiden avulla pystyimme kiinnittämään analyysissamme 
huomion eri ammattiryhmien näkemyksiin sosiaalityön asiantuntijuuden jäsentymisestä. Mäntyrannan ja Kailan (2008) mukaan fokusryhmähaastattelua pidetään laadullisena menetelmänä, jossa tutkija ylläpitää ryhmäkeskustelua pyrkien ymmärtämään tutkittavaa ilmiötä ja tavoittelemaan eri näkökulmia. Lisäksi fokusryhmähaastattelut sopivat hyvin aineistonkeruumenetelmäksi silloin, kun haastateltavat edustavat samaa ammattiryhmää. (Mt., 1507.)

Fokusryhmähaastatteluiden yhtenä haasteena voidaan pitää tutkimukseen osallistuvien henkilöiden vähäistä määrää (Sim \& Waterfield 2019).Tavoitteena oli saada tutkimuksen kaikkiin viiteen haastatteluun vähintään neljä ammattilaista mukaan ja tämä toteutuikin muissa paitsi toimintaterapeuttien haastattelussa. Fokusryhmähaastatteluissa haastateltavien valinnan tavoitteena ei ole tilastollinen edustavuus, vaan koota ryhmä haastateltavia, jotka pystyvät tuomaan tutkittavaan asiaan uusia näkökulmia (ks. Mäntyranta \& Kaila 2008), jolloin vähäinenkin haastateltavien määrä riittää luotettavan kuvan muodostamiseen tutkittavasta ilmiöstä (Guest ym. 2017).

Fokusryhmähaastatteluiden keskustelun pohjana hyödynnettiin aiemmin tehtyä esitutkimusta (e-kysely), joka tuotti fokusryhmähaastatteluiden tueksi sosiaalityön tehtäviä nuorisopsykiatriassa kuvaavat luokitukset: sosiaalisen tilanteen kartoittaminen ja arviointi, perhe- ja verkostotyö, palveluverkoston koordinointi ja konsultointi, hoitotyö ja terapeuttinen työ sekä taloudelliset asiat. Fokusryhmähaastatteluissa syvennyttiin tarkastelemaan sosiaalityön asiantuntijuuden jäsentymistä kyseisten luokkien avulla (Neergaard \& Leitch 2015, 273). Fokusryhmähaastatteluissa ammattilaisia pyydettiin jokaisen luokan osalta määrittelemään ja kuvaamaan tarkemmin sosiaalityön keskeisiä tehtäviä nuorisopsykiatrian avohoidossa osana moniammatillista yhteistyötä. Fokusryhmähaastattelut nauhoitettiin ja litteroitiin sanasta sanaan. Haastatteluiden käsin kirjoitettujen litteroitujen sivujen määrä oli 110.

Haastattelut analysoitiin aineistolähtöistä sisällönanalyysiä hyödyntäen (mm. Stemler 2001). Analyysin ensimmäisessä vaiheessa aineistosta yliviivattiin eri väreillä jokaisen ammattiryhmän kuvauksia ja tulkintoja sosiaalityön asiantuntijuudesta. Erillisen tarkastelun jälkeen ammattiryhmien sisällöllisesti samankaltaiset kuvaukset ja tulkinnat yhdistettiin ja ryhmiteltiin omiksi kokonaisuuksiksi (mm. Mayring 2004). Analyysin viimeisessä vaiheessa muodostimme ryhmitellyistä kokonaisuuksista nuorisopsykiatrian sosiaalityön asiantuntijuutta kuvaavat ylä- ja alakategoriat (ks. kuvio 1). Aineistolähtöisen sisällönanalyysin avulla aineistosta voidaan muun muassa koodata ja muodostaa ilmiötä kuvaavia kategorioita (mm. Stemler 2001). 


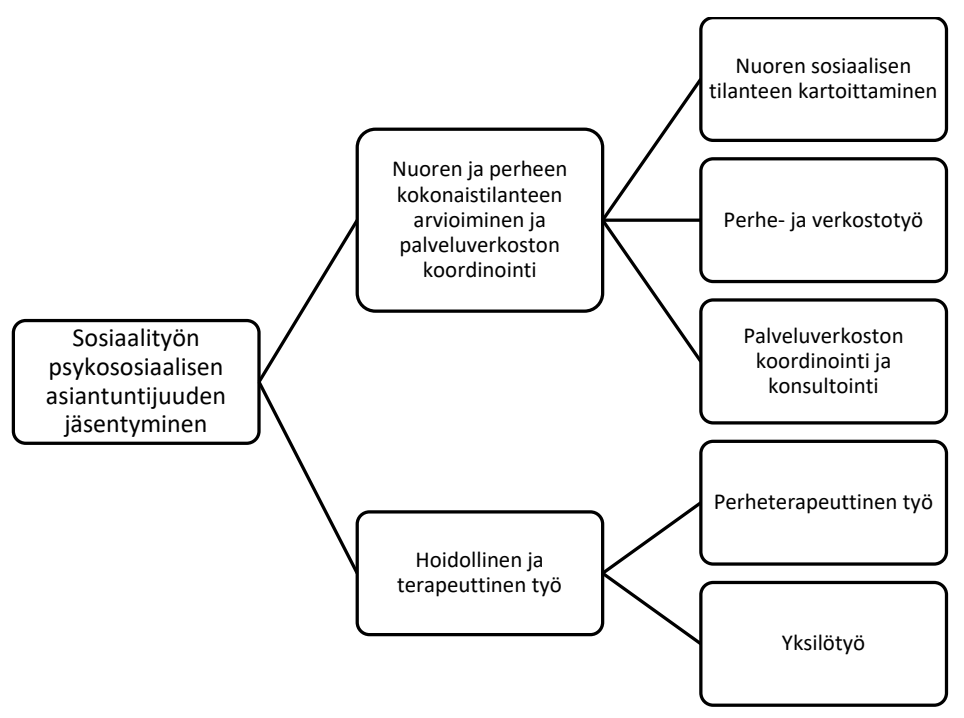

Kuvio 1. Sosiaalityön psykososiaalisen asiantuntijuuden jäsentyminen nuorisopsykiatriassa

Yhdistämällä eri ammattiryhmien tulkintoja toisiinsa muodostimme kokonaiskuvan sosiaalityön asiantuntijuuden jäsentymisestä nuorisopsykiatriassa. Analysoinnissa huomiota kiinnitettiin myös ammattiryhmien eriäviin näkemyksiin ja tulkintoihin, joita esitettiin esimerkiksi sosiaalityön määrittymisestä terapeuttisena työnä. Mäntyrannan ja Kailan $(2008,1507)$ mukaan fokusryhmähaastattelulla pyritään ymmärtämään tutkittavaa ilmiötä ja tuomaan siihen uusia näkökulmia sekä tietoa, jota ei aikaisemmin ole ollut. Aineistolähtöinen sisällönanalyysi valittiin tutkimuksen analysointimenetelmäksi, koska sen avulla saimme aineistosta parhaiten jäsennettyä keskeisimmät sosiaalityön psykososiaalista asiantuntijuutta kuvaavat kategoriat.

Tutkimusta suunniteltaessa otettiin huomioon tutkittavien anonymiteetin säilyminen. Fokusryhmähaastatteluissa ei missään vaiheessa kysytty ammattilaisten nimiä, ainoastaan ammattinimike toimi tunnisteena. HUS:n nuorisopsykiatrian avohoidossa työskentelee yli 300 ammattilaista, joten yksittäisten haastateltavien tunnistaminen on melko epätodennäköistä pelkän ammattinimikkeen avulla. Kaikilta tutkimukseen osallistuneilta pyydettiin kirjallinen suostumus tutkimukseen osallistumisesta. Tutkimuksen tekopaikka (HUS) on mainittu, koska polikliinisen työn toimintatavat nuorisopsykiatriassa eri sairaanhoitopiireissä voivat vaihdella. Tutkimus on saanut HUS:n eettisen toimikunnan puoltolausunnon ja tutkimusluvan vuonna 2017. Tutkimusprosessi on pyritty pitämään mahdollisimman läpinäkyvänä kuvaamalla tutkimusprosessin eri vaiheet seikkaperäisesti (ks. Nikander 2010). 


\section{NUOREN JA PERHEEN}

\section{KOKONAISTILANTEEN ARVIOIMINEN}

JA PALVELUIDEN KOORDINOINTI

\section{Nuoren sosiaalisen tilanteen kartoittaminen ja arviointi}

Sosiaalityöntekijöiden haastattelussa psykiatrian sosiaalityöntekijän tärkeimmiksi työtehtäviksi kuvattiin nuoren elämäntilanteen kartoitus- ja arviointityö. Sosiaalityöntekijät toivat esille haastattelussa, että nuoren sosiaalisen tilanteen kartoituksella ja arvioinnilla saadaan muodostettua kokonaiskuva nuoren sen hetkisestä elämäntilanteesta, verkostoista sekä perhe- ja kasvuolosuhteista yhdistämällä sosiaalityöntekijän asiantuntemus ja nuoren kokemus. Sosiaalityöntekijöiden esille tuoman näkemyksen mukaan kartoitus ja arvio sisälsi myös suunnitelman palveluihin ohjaamisesta ja sosiaalityön suosituksista. Nurmi (2016) toteaa tutkimuksessaan, että sosiaalityöntekijät nuorisopsykiatriassa tekevät sosiaalisen tilanteen kartoituksia ja arvioita nuoren kokonaistilanteesta arvioiden kartoituksen perusteella kuntoutuspalveluiden tarvetta. Sosiaalityön psykososiaalisen työn lähtökohtana mielenterveyspalveluissa on kartoittaa potilaan kokonaistilannetta (Corcoran \& Walsh 2016), kiinnittäen huomiota yksilön kuntoutumisen, taloudellisen tilanteen ja sosiaalisten suhteiden tarkasteluun (Muralidhar ym. 2012, 71-76). Sosiaalityöntekijät totesivat haastattelussa, että laajat sosiaalisen tilanteen kartoitukset ja arviot tehdään yleensä itsenäistymisvaiheessa oleville nuorille ikään kuin yhteenvetona nuorisopsykiatrisesta hoidosta ja muista tukipalveluista. --ois tosi tärkee, et sit kun ne siirtyy aikuispuolelle, että tota, ite oon tehnyt silleen et nyt mä sit istun vaan alas ja mietin et mitä tässä on tapahtunut ja kirjaan sen, et se on niinku tavallaan osa sitä prosessia ja sit mä teen jossain vaiheessa yhteenvedon, joka etenkin, kun on tällainen joka on siirtymässä pois, et se on niinku se kokonaisuus jossain kirjattuna ja siellä on suunnitelmaa, jossa on sosiaalityön näkökulmaa ja se mitä on tehty, kun sehän ei näy sieltä NPSYlehdeltä. (sosiaalityöntekijä)

Muidenkin ammattiryhmien haastatteluiden analyysin perusteella sosiaalityöntekijältä odotetaan ymmärrystä psyykkisten tekijöiden ja oireiden vaikutuksesta nuoren toimintakykyyn, joka tulee huomioida arviointia tehdessä. Lääkärit toivat esille myös sitä, että sosiaalityöntekijän tekemän kartoituksen pitäisi olla nuoren nykytilanteen lisäksi strukturoitu arvio aikaisemmista hoitoketjuista ja asiakkuuksista sekä niiden vaikuttavuudesta. Tällöin kartoituksen avulla voidaan suunnitella jatkoa. Arvion koettiin tätä kautta toimivan nimenomaan syötteenä nuoren tarvitsemien palveluiden aloittamiselle ja palveluihin pääsylle, esimerkiksi lastensuojeluun tai vammaispalveluiden piiriin. Myös sairaanhoitajat kokivat tärkeäksi sen, että sosiaalityöntekijä tarkastelee, mitä palveluita nuori on jo saanut, esimerkiksi lastensuojelussa.

Näillä, joilla on niinku useita hoitokontakteja ollu aikaisemmin, tai jotain lastensuojeluinterventioita niin siinä varmaan ois tärkeetä tehdä se arvio, et mitä siellä on oikeasti tapahtunut, et siit on niinku oikeesti ollut hyötyy ja mist taas näkyy et siit on ollu niinku haittaa. Et se miten mä oon sen niinku hahmottanut et tarkoitus on niinku kuitenkin kerätä sitä aikaisempaa mate- 
riaalia myös et ei pelkkää nykytilannetta tai se mitä mä oon nähnyt et käydä läpi niitä asiakirjoja, niin sellaisissa tilanteissa näkisin et se on äärimmäisen tärkeää, koska se olisi niinku sellaista strukturoitua arviota. (läkäri)

Psykologit ja toimintaterapeutit kuvasivat sosiaalityöntekijöiden tekemää arviota tutkimuksena, jossa sosiaalityöntekijä kartoittaa nuoren palveluiden tarvetta, oikeuksia taloudellisiin etuuksiin ja ohjaa oikeanlaisten palveluiden piiriin syrjäytymisen ehkäisemiseksi. Pirttijärven (2013) tutkimuksen mukaan psykiatrisessa sairaalassa sosiaalityön yleisenä käytäntönä on selvittää potilaalle kuuluvat sosiaaliturvaetuudet. Haastatteluissa sosiaalityöntekijällä koettiin olevan tietotaitoa erityisesti sosiaaliturvaan ja nuoren oikeudellisiin kysymyksiin liittyvissä asioissa. Näitä taitoja tulisi entistä paremmin osata hyödyntää nuorisopsykiatrisessa hoidossa ja kokonaistilanteen arvioinnissa.

Vaikka ammattilaiset jäsensivät sosiaalityön asiantuntijuuden osaksi nuoren kokonaistilanteen kartoitusta ja arviota, niin käsitetasolla arvioinnista käytettiin kirjavia ilmauksia kuten sosiaalisen toimintakyvyn tutkimus tai tilannearvio. Ammattilaiset, sosiaalityöntekijöitä lukuun ottamatta, toivoivat lisätietoja sosiaalityöntekijän tekemästä nuoren kokonaistilanteen arviosta ja sen tarkempaa kuvaamista osana työnjaon selkeyttämistä ja suhdetta muihin nuorisopsykiatriassa tehtäviin tutkimuksiin.

Perhe - ja verkostotyö

Nuorisopsykiatrisessa työskentelyssä nuoren perhe ja verkosto kuuluvat nuorisopsykiatrisen hoitotyön kokonaisuuteen. Aineiston analyysin perusteella sosiaalityöntekijöiden asiantuntijuus nuorisopsykiatrisessa työskentelyssä kiinnittyy nuoren sosiaalisen toimintakyvyn ja perheen kokonaistilanteen arviointiin suhteessa heidän tuen ja palveluiden tarpeeseensa. Sosiaalityöntekijät jäsensivät perhetyön osaksi vanhempien arjen tukemista ja nuoren kasvuolosuhteiden kartoittamista.Verkostotyössä korostettiin yhteisen ymmärryksen saamista ja arviointia nuoren ja perheen tilanteesta. Sosiaalityöntekijät kuvasivat verkostotyötä myös käsitteellä rajapintatyöskentely (vrt. Kuntaliitto 2017), jolla tarkoitettiin esimerkiksi lastensuojelun kanssa tehtävää moniammatillista arviointia ja kokonaisvaltaisen suunnitelman laatimista.

Ja mulla tuli mieleen se, että nykyisin on paljon sitä rajapintatyöskentelyä lastensuojelun kanssa, että yhdessä tehdään sitä monialaista arviointia, että niin kuin yhdessä muodostetaan sitä käsitystä ym. nuoren ja perheen tilanteesta. Se on ollut hirmu antoisaa (sosiaalityöntekijä)

Haastatteluista ilmenee, että perhe- ja verkostotyötä tekevät kaikki nuorisopsykiatrian ammattiryhmät. Sosiaalityöntekijän asiantuntemusta tarvitaan erityisesti moniongelmaisissa tapauksissa, joissa sosiaalityön asiantuntijuuden koetaan tuovan työskentelyyn laaja-alaisempaa, yhteiskuntatason näkökulmaa. Verkostoneuvotteluissa nuorisopsykiatrian sosiaalityöntekijän tehtävänä on toimia psykiatrisen hoidon edustajana sosiaalityön viitekehyksellä. Perhe- ja verkostotyön yhdistelmässä sosiaalityöntekijän asiantuntijuuden toivottiin tuovan mahdollisuuksia nuorisopsykiatrisen hoidon toteutumiselle, 
toisin sanoen hoidon esteiden poistamiselle ja perheen tukemiselle.

Perhe- ja verkostotyössä niinku poliklinikalla, niin siinä korostuu ennen kaikkea se, miten mä sen kuvittelen, niin sosiaalityöntekijä kattoo sitä ennen kaikkea niinku $y$ hteiskunnan tasolta, jos mä katon sitä hoitotyöntekijänä yksilön tasolta ym. Et hän tuo semmosen laajemman lisän siihen et hän tuo sen ikään kuin laajemman näkökulman ja kattoo sitä suhteessa perheeseen, suhteessa verkostoon ja suhteessa yhteiskuntaan ja tuo sitä kautta apua ja mahdollisuuksia nuorelle ja perheelle. (sairaanhoitaja)

Toimintaterapeuttien, sairaanhoitajien ja psykologien haastatteluissa sosiaalityöntekijän tekemä perhe- ja verkostotyö jäsennettiin osaksi moniammatillista työparityöskentelyä, jossa sosiaalityöntekijän odotetaan arvioivan erityisesti nuoren kasvuolosuhteita ja perheen arkea. Sosiaalityöntekijän tekemä perhetyö näyttäytyi vanhemmuuden, perheen arjen ja vuorovaikutuksen tukemisena, joka perustui nuoren kasvuolosuhteiden ja perheen palveluiden tarpeen arviointiin.

Mun mielest se on pitkälti sitä, että hän selvittelee just et mitä palveluita perhe esimerkiksi saa just lastensuojelusta tai mitä tukitoimia koulussa on ja jotenkin ehkä toimii sellaisena linkkinä tän yksilötyöntekijän ja verkoston välillä, että se yksilötyöntekijän kaikki aika ei kulu siihen selvittämiseen ja sen haltuun ottamiseen. (toimintaterapeutti)

Sosiaalityöntekijöiden tekemä perhe- ja verkostotyö näyttäytyi aineiston analyysin pohjalta laaja-alaisena ja monimuotoisena sosiaalityön asiantuntijuutta kuvaavana kokonaisuutena, jossa yhdistyvät sekä arvioinnin ja verkostoyhteistyön että perhetyön elementit. Perhetyö jäsennettiin ammattilaisten keskusteluissa myös perheterapeuttiseksi työksi ja vanhempien psykososiaaliseksi tukemiseksi. Kansainvälisissä tutkimuksissa todetaan, että sosiaalityön keskeisenä tehtävänä mielenterveyspalveluissa on huomioida potilaan perhesuhteet ja nähdä perhe voimavarana potilaan kuntoutumiselle (mm. Kean 2009). Tämä näkemys korostuu erityisesti nuorisopsykiatriassa, jossa perheen tuki ja perhetyö vaikuttaa olennaisesti nuoren kuntoutumisen edistymiseen (mm. Kaminski ym. 2008).

\section{Palveluverkoston koordinointi ja konsul- tointi}

Sosiaalityöntekijän ammattitaitoa ja asiantuntijuutta jäsennettiin haastatteluissa yhteiskunnan palvelujärjestelmän ja sosiaaliturvan näkökulmasta. Sosiaalityöntekijältä odotettiin laajaalaista tietämystä sekä psykiatrisista hoitomuodoista ja terveydenhuollon ulkopuolisesta palveluverkostosta että näiden välisestä suhteesta, ja mahdollisuuksista nuoren sosiaalisen toimintakyvyn parantamisessa. Sosiaalityöntekijät pitivät keskustelussa tärkeänä sitä, että ymmärrys ja ajankohtainen tietämys psykiatrian ja sosiaalihuollon palveluista säilyy sosiaalityöntekijällä.

Niin mä olen samaa mieltä siitä, että ajan hermoilla pysyminen, koska koko ajan muиttuu nää palvelut ja tietoa mitä palveluita on psykiatrian puolella ja mitä lastensuojelussa, sit on paljon helpompi ohjata kun tietää mitä voi tarjota, se helpottaa sitä koordinointia ja ehkä myös oikea-aikaisuutta. (sosiaalityöntekijä) 
Lääkärien ja sairaanhoitajien haastattelujen pohjalta muodostui kuva, että he ovat saaneet apua sosiaalityöntekijöiltä etenkin Kelan etuuksiin liittyvissä kysymyksissä niin yhteistyöpalavereissa kuin erillisissä konsultaatiotapaamisissa. Sairaanhoitajat ja lääkärit arvostivat sosiaalityöntekijän osaamista erityisesti palveluverkostoa ja Kelan etuuksia koskevissa kysymyksissä (vrt. Hotari \& Metteri 2010, 12). Sairaanhoitajat kuvasivat syrjäytymisvaarassa olevien nuorten kohdalla sosiaalityön merkitystä yhteiskunnan tukipalveluiden ja lainsäädännön asiantuntijana.

Mikä olis niinku tosi tärkeää olis se, että sosiaalityöntekijällä olis kokonaiskuva muista toimijoista niinku sellanen kuva, eli just tästä niinku palveluverkostosta, et niinku mitä muista toimijoita tällä alueella on ja et jotenkin et hänen se osaaminen olis niinku semmosta, et kun hän kuulee niinku tiimissä jonkun semmosen nuoren, jolla on monenlaista haastetta esimerkiksi niinku koulupudokkaita tai esimerkiksi sellaisia jotka on peruskoulun jo päättäneitä, mut ei ole edennyt niinku mihinkään opintoihin, et mikä muu niinku tän yhteiskunnan tuki tällä meidän alueella on, et hän olis ikäänkuin sellainen asiantuntija, joka vois bongata ikään kuin sellaisia meidän yhteistyökumppaneita tavallaan tohon palveluverkostonkoordinointiin sellainen alueellinen osaaminen.(sairaanhoitaja)

Palveluverkoston koordinointi ja konsultointi koettiin selkeästi sosiaalityön asiantuntijuutta vaativaksi työkokonaisuudeksi. Sosiaalityöntekijältä toivottiin palveluverkoston koordinoinnin ja konsultoinnin toteuttamiseksi alueellista palveluverkoston ja sosiaaliturvalainsäädännön tuntemusta sekä mahdol- lisuuksia tiedottaa alueen toimijoista moniammatilliselle työryhmälle.

\section{Terapeuttinen JA HOIDOLLINEN TYÖ}

\section{Perheterapeuttinen työ}

Sosiaalityöntekijän tekemälle hoidolliselle ja terapeuttiselle työlle oli haastatteluissa haastavaa löytää selkeää määritelmää, vaikka sosiaalityö jäsennettiin myös hoidollisena tai terapeuttisena vuorovaikutustyönä. Sosiaalityöntekijän tekemän perheterapeuttisen ja hoidollisen yksilötyön koettiin heikentävän monitieteellistä yhteistyötä, jos sosiaalityön ydinosaaminen jää vähäisemmälle. Savolainen (2012, 150-151) toteaa, että psykoterapeuttisten menetelmien käyttö voi johtaa mielenterveyssosiaalityössä sosiaalityön ydinosaamisen kaventumiseen ja tietopohjan ohentumiseen. Leinonen (2018) kuitenkin yhdistää tutkimuksessaan sosiaalityön yhteiskuntatieteellisen osaamisen ja vuorovaikutteisen hoidollisen työn sosiaalityön terapeuttiseksi asiantuntijuudeksi.

Sosiaalityöntekijän tekemä perheterapeuttinen työ näyttäytyi aineiston analyysin pohjalta vahvasti perheen arjen parantamiseen ja vanhemmuuden tukemiseen painottuvana työskentelynä perheterapeuttisin menetelmin ( $\mathrm{mm}$. Väänänen 2013). Ammattilaisten oli vaikea tehdä rajanvetoa perhetyön ja perheterapeuttisen työn välillä, mikä osaltaan aiheutti päällekkäisyyttä ammattilaisten määrittelyissä.

Lääkäreiden haastattelussa suhtauduttiin osittain kriittisesti sosiaalityöntekijöiden tekemään perheterapeuttiseen 
työskentelyyn. Osa lääkäreistä koki, että sosiaalityöntekijän tekemä terapiatyö tai perhetyö on jäänyt epäselväksi nuorisopsykiatriassa. Lääkärit toivoivat sosiaalityöntekijöiden työnkuvan terävöittämistä suhteessa hoidolliseen työhön sekä interventiomenetelmiin. Interventioilla tarkoitetaan asiakkaan arkea ja toimintakykyä tukevia strukturoituja menetelmiä (mm. Gustafsson 2009).

Mä viel yhden jutun sanon, kun se hoidollinen tai terapeuttinen epämääräinen työ ei kuulu, mut siis tota niinku sellaisii strukturoituja hoitomenetelmiä, missä sosiaalityöntekijä pystyy niinku parhaiten hyödyntää, et MDFT on yks varmaan sielt niinku koulutuksesta johtuen, mut plipäätään siin on se niinku verkosto, tai sit ne niinku terapeuttiset perheinterventiot niin niitä odotellessa, et se tulis niinku selkeämmin määritellyks et mitä se on. (lääkäri)

Osa ammattilaisista puolestaan piti merkittävänä sitä, että sosiaalityöntekijä, jolla on perheterapiakoulutus, osallistuu vanhempien arjen tukemiseen perheterapeuttisin menetelmin. Erityisesti työparityöskentelyssä hoitopoliklinikoilla koettiin, että perheterapiakoulutuksen omaavan sosiaalityöntekijän työ vanhemmuuden tukemiseksi on arvokasta ja tarpeellista.

\section{Yksilötyö}

Ammattilaisten haastatteluissa yksilötyöksi kuvautuivat nuorten terapiatapaamiset tilanteissa, joissa sosiaalityöntekijä pystyi oman koulutuksensa ja ammattitaitonsa puitteissa vastaamaan nuoren tuen tarpeeseen terapeuttisin tai hoidollisin menetelmin. Toimintaterapeutit ja psykologit kokivat sosiaali- työntekijän tekemän yksilötyön tuovan syvyyttä ja ymmärrystä nuorisopsykiatriassa potilaina olevien nuorten toimintakyvyn ja hoitotyön vaikuttavuuden ymmärtämiseen nuorten syrjäytymisen ehkäisyn osalta. Sosiaalityöntekijät kokivat, että he tarkastelevat nuoren ja perheen elämäntilannetta suhteessa yhteiskuntaan tuoden terapeuttiseen työskentelyyn sosiaalityön orientaation, jota muilla ammattiryhmillä ei ole. Yleisesti sosiaalityössä tehtävään yksilötyöhön liittyy laajempi orientaatio nähdä ihminen sosiaalisissa yhteyksissään (mm. Juhila 2006).

\section{Ehkä sen verran vielä, kun mä olen niinku nuorisopsykoterapeutti niinku et tehnyt si- täkin työtä, mut kyl mä sit ajattelen et mä niinku oon tavannut niitä nuoria aikaisem- min, kun tein sitä ni kyl mä sit ajattelin, et jonkun nuoren kohdalla mä olen sosiaali- työntekijän orientaatiolla hyvin vahvasti, et en mä koe sellaista sisäistä ristiriitaa et se söis sosiaalityöntekijyyttä. (sosiaalityönte- kijä)}

Lääkärit ja sairaanhoitajat toivat haastatteluissa esille näkökulman siitä, etteivät terapiatyötä tai hoidollista työtä tekevät sosiaalityöntekijät saa unohtaa sosiaalityöntekijän ammatti-identiteettiään osana monialaista yhteistyötä. Samalla lääkärit kuitenkin korostivat, että sosiaalityöntekijän tulee ymmärtää, miten psyykkiset oireet vaikuttavat nuoren toimintakykyyn ja miten hoidolla voidaan vaikuttaa psyykkisiin oireisiin. Haastattelussa osa sosiaalityöntekijöistä puolestaan koki fokusoitujen terapiamuotojen heikentävän moniammatillista yhteistyötä nuorten ja perheiden tuen tarpeeseen vastaamisessa. 
Nyt on tullut nämä lyhytterapiakoulutukset niin kun se tavallaan se tiimi on menettänyt merkityksensä ja se moniammatillisuus tavallaan, että kun on niin paljon näitä kognitiivisia ja muita suuntauksia ja lyhyempiä, mitä sitten poliklinikalla toteutetaan ja ihmiset on menossa koko ajan koulutuksissa (sosiaalityöntekijä)

Haastatteluissa nousi esille, että nuoria tapaavat pääsääntöisesti terapiakoulutuksen saaneet sosiaalityöntekijät, mutta nuoria tavataan myös tilanteissa, joissa muilla työntekijöillä ei työkiireen vuoksi ole siihen aikaa. Työkiire voi aineiston analyysin perusteella aiheuttaa sen, että sosiaalityöntekijät tapaavat nuoria ilman lisäkoulutusta tai terapiatyön kokemusta. Tällainen tilanne saattaa syntyä silloin, kun lähetteiden määrä kasvaa eikä hoitotyön resursseja ole tarpeeksi.

\section{JOHTOPÄÄTÖKSET JA POHDINTA}

Tutkimus sijoittuu aikaan, jossa nuorisopsykiatrian hoitotyön rakenteita on uudistettu. Tutkimuksessa on tarkasteltu, miten nuorisopsykiatrian avohoidon eri ammattiryhmät määrittelevät sosiaalityön asiantuntijuuden jäsentymisen moniammatillisessa yhteistyössä. Tutkimusaineiston perusteella ammattilaiset kokivat sosiaalityön tärkeänä osana moniammatillista yhteistyötä ja nuoren hoitoprosessia. Sosiaalityön työtehtävien nähtiin olevan sidoksissa nuoren ja perheen sosiaalisiin ongelmiin tai vuorovaikutushaasteisiin, joihin pyrittiin vaikuttamaan esimerkiksi perhetyön keinoin.

Tutkimuksen valossa nuorisopsykiatrian sosiaalityöntekijä huomioi työssään sekä nuoren toimintakyvyn psyykkiset että sosiaaliset tekijät. Niin kansallisessa kuin kansainvälisissä tutkimuksissa psykososiaalinen työskentely huomioi ihmisen sisäisen ja ulkoisen, eli psykologisen ja sosiaalisen, maailman (Coulshed ym. 2012, 108-109; Vuori 2001) ja Engelin (1980, 535-543) mukaan psykososiaalisten tekijöiden huomiotta jättäminen moniammatillisessa yhteistyössä heikentäisi potilaan kokonaistilanteen arviointia ja hoitoa.

Tämän tutkimuksen mukaan moniammatillisessa nuorisopsykiatriassa sosiaalityön psykososiaalisella asiantuntijuudella on kaksoisrooli 1) nuoren ja perheen kokonaistilanteen arvioimisessa ja palveluiden koordinoinnissa sekä 2) terapeuttisessa ja hoidollisessa työskentelyssä. Tähän vastaajien mukaan vaikuttivat sosiaalityöntekijän taustakoulutus sekä poliklinikan hoitotyön tavoitteet ja toimintakulttuuri. Sosiaalityöntekijän työtehtäviä ovat nuoren sosiaalisen tilanteen kartoittaminen ja arviointi, perhe- ja verkostotyö, palveluverkoston koordinointi ja konsultointi sekä perheterapeuttinen työ ja yksilötyö (ks. kuvio 1). Taloudellisten asioiden selvittely miellettiin osaksi sosiaalityöntekijän tekemää nuoren sosiaalisen tilanteen arviota, perhe- ja verkostotyötä sekä palveluverkoston koordinointia ja konsultointia. Tutkimuksen mukaan sosiaalityöntekijän työskentelyn lähtökohtana on sosiaalityön asiantuntemuksen yhdistyminen nuorisopsykiatrian vaatimuksiin. Sosiaalityöntekijältä edellytetään ymmärrystä psykologiasta ja psyykkisten oireiden vaikutuksesta nuoren toimintakykyyn. Tämän ymmärryksen kautta nuorta ja perhettä voidaan tukea sosiaalityön keinoin nuorisopsykiatrian 
kontekstissa. Psykososiaalisessa sosiaalityössä korostuu psykologinen ymmärrys ihmisen käyttäytymisestä ja persoonallisuudesta (Granfelt 1993, 177-179; Bower 2005).

Tutkimuksen tulokset ovat osin yhteneväisiä muiden psykososiaalista sosiaalityötä mielenterveyspalveluissa tarkastelevien tutkimusten kanssa. Aiempien tutkimusten mukaan mielenterveyspalveluissa tehtävä kokonaistilanteen arviointi on yksi keskeisimmistä sosiaalityön psykososiaalisen työskentelyn käytänteistä (Muralidhar ym. 2012; Korpela 2014; Corcoran \& Walsh 2016). Alaikäisten kohdalla arvioinnissa huomioidaan erityisesti kasvuolosuhteet ja perhetilanne ( $\mathrm{mm}$. Leppälahti 2014). Nuorisopsykiatrian sosiaalityöntekijän tekemä kartoitus ja arvio toimivat perustana palveluverkoston koordinoinnille ja sosiaaliturva -etuuksien vireille saattamiselle sekä perhe- ja verkostoyhteistyön käynnistämiselle. Sosiaalityön terapeuttinen ja hoidollinen työskentely tai interventiot perustuvat potilaasta tehtyyn kokonaistilanteen arviointiin ja kartoitukseen (Muralidhar ym. 2012, 71-76; McCrae ym. 2005).

Nuorisopsykiatrian sosiaalityöntekijöiden tekemän terapeuttisen työn painopiste on vanhemmuuden ja perheen vuorovaikutuksen tukemisessa perheterapeuttisten menetelmien avulla. Perhetyö ja terapiatyö näyttäytyivät tutkimuksessa hyvin samankaltaisina työskentelyn muotoina, jossa korostui perhekeskeinen lähestymistapa. Perhekeskeisellä työllä pyritään tukemaan potilaan ihmissuhteita ja lähiverkostoa kuntoutumista edesauttavasti (mm. Antikainen-Juntunen 2005, 98; Venkat ym. 2014, 127). Psyykkisesti sairaiden lasten ja nuorten hoidossa toipuminen vaatii voimia koko perheeltä. Lapsen ja nuoren itsensä lisäksi myös perheiden kuntoutustarpeen ja ongelmien tunnistaminen on näin ollen tärkeää. (Leppälahti 2014, 47-48.) Perhekeskeisessä työskentelyssä sosiaalityön kompetenssi on perheen vuorovaikutuksen ja dynamiikan tarkastelussa ja sen tukemisessa (ks.Väänänen 2013) perhetyön tai perheterapian keinoin. Nuorisopsykiatriassa sosiaalityöntekijät tekevät myös terapiatyötä tai hoidollista työtä nuorten kanssa. Pääääntöisesti nuoria hoidetaan sosiaalityöntekijän toimesta tilanteissa, joissa sosiaalityöntekijät kykenevät vastaamaan nuoren tuen tarpeeseen oman osaamisensa ja koulutustaustansa puitteissa.

Sosiaalityöntekijältä odotetaan sosiaalityön asiantuntijuuden lisäksi ymmärrystä psyykkisten oireiden vaikutuksista nuoren toimintakykyyn sekä ymmärrystä psykiatrisesta hoitotyöstä, vaikka sosiaalityöntekijä ei itse toimisikaan hoitotyöntekijänä tai terapeuttina. Sosiaalityöntekijän odotetaan yhtäältä ymmärtävän hoidollisen työn kieltä ja toisaalta sosiaalityöntekijältä odotetaan tulkkausta sosiaalipalvelujärjestelmästä ja sosiaalihuollon toimintatavoista. Nuorisopsykiatrinen sosiaalityö on siis erikoistunut sosiaalityön lisäksi nuorten psykiatrisiin kysymyksiin (mm. Tiihonen ym. 2019, 199), mikä käytännössä tarkoittaa sitä, että sosiaalityöntekijän on kyettävä tunnistamaan yhteiskunnan ja palvelujärjestelmän tuomat mahdollisuudet tukea nuoren sosiaalista toimintakykyä. Tiedon avulla moniammatillinen tiimi rakentaa kokonaiskuvaa nuoren tilanteesta sekä hoidon ja palveluiden tarpeesta. 
Tutkimusaineistosta ei noussut esiin, että nuorisopsykiatrian muuttuneet rakenteet, kuten fokusoidut hoidot, olisivat haastateltujen ammattiryhmien näkökulmasta ratkaisevasti vaikuttaneet sosiaalityöntekijän työnkuvaan. Havaittavissa on kuitenkin, että sosiaalityön asiantuntijuus näyttäytyy osalle ammattilaisista hiukan epäselvästi määrittyvänä terapeuttisena tai hoidollisena työnä, jolloin sosiaalityön arvioinnille ja moniammatilliselle keskustelulle jää vähemmän aikaa. Paine hoidollisen tai terapeuttisen työn suuntaan tulee organisaation tasolta tilanteissa, joissa työkiire ajaa sosiaalityöntekijät tekemään yksilötyötä hoidollisin menetelmin. Tämä on osittain ristiriidassa sen kanssa, että sosiaalityöntekijän työnkuvaa ja asemaa erityistyöntekijänä on uudistuksessa nimenomaan pyritty selkiyttämään. Sosiaalityön terapiatyöstä tai interventioista nuorisopsykiatriassa on olemassa vain vähän käytäntöön perustuvia tutkimuksia. Näin ollen myös strukturoidut ja jäsentyneet terapeuttiset tai hoidolliset työskentelymallit tuntuvat puuttuvan. Nuorisopsykiatrian sosiaalityön työnkuvaa jäsennettäessä huomiota tulisi kiinnittää sosiaalityön työtehtävien, kuten sosiaalisen tilanteen kartoituksen ja arvioinnin systemaattiseen hyödyntämiseen ja terapeuttisten menetelmien kehittämiseen. Nuorisopsykiatrian psykososiaalisessa sosiaalityössä yhdistyy niin psykiatrinen kuin sosiaalinenkin osaaminen.

\section{KirjallisuUs}

Adams, Kim \& Hean, Sarah \& Sturgis, Patrick \& Clark Macleod, Jill (2006) Investigating the factors influencing pro- fessional identity of first-year health and social care students. Learning in Health and Social Care 5 (2), 55-68. https://doi. org/10.1111/j.1473-6861.2006.00119.x Adams, Robert \& Dominelli, Lena \& Payne, Malcom (2009) Critical practice in social work. Basingstoke: Palgrave Macmillan. https://doi.org/10.1007/978-0-23036586-5

Ambrose-Miller, Wayne \& Ashcroft, Rachel (2016) Challenges faced by social workers as members of interprofessional collaborative health care teams. Health and Social Work 41 (2), 101-109. https:// doi.org/10.1093/hsw/hlw006

Antikainen-Juntunen, Eija (2005) Sosiaalityö psykiatrisessa työkyvyn arvioinnissa. Sosiaalityöntekijöiden käsitysten arviointi empowermentin näkökulmasta. Sosiaalityön ammatillinen lisensiaatin tutkimus. Tampereen yliopisto. Sosiaalipolitiikan ja sosiaalityön laitos. https://trepo.tuni.fi/bitstream/ handle/10024/76407/lisuri00035. pdf?sequence $=1$ Luettu 19.1.2019.

Berner, Gunnar \& Johnsson, Lisbeth (1988) Teori för psykosocialt arbete. Stockholm: Natur och Kultur.

Bertz, Bender J. \& Murdock, Karla K. \& Mitchell, Daphne K. (2005) Children's asthma, internalizing problems, and social functioning: an urban perspective. Journal of Child and Adolescent Psychiatric Nursing 18 (4), 181-197. https://doi. org/10.1111/j.1744-6171.2005.00026.x

Bland, Robert (2014) Context of social work practice: an introduction. Teoksessa Francis Abraham P. (toim.) Social work in mental health: contexts and theories for practice. London: Sage, 3-6. https:// doi.org/10.4135/9789351507864.n1

Bower, Marion (2005) Psychoanalytic theory for social work practice. Teoksessa Marion Bower (toim.) Psychoanalytic theory for social work practice. Thinking under fire. London and New York: Routledge, 3-14. https://doi. org/10.4324/9780203341155_chapter_1

Corcoran, Jacqueline \& Walsh, Joseph (2016). Clinical assessment and diagnosis in social work practice. Third edition. Oxford: University Press.

Coulshed, Veronica \& Orme, Joan (2012) 
Social work practice. Fifth edition. London: Palgrave MacMillan. https://doi. org/10.1007/978-0-230-36779-1

D’Amour, Danielle \& Oandasan, Ivy (2005) Interprofessionality as the field of interprofessional practice as interprofessional education: an emerging concept. Journal of Interprofessional Care (19) 1, 8-20. https://doi. org/10.1080/13561820500081604

Engel, George (1977) The need for a new medical model: a challenge for biomedicine. Science 196 (4286), 129-136. https://doi.org/10.1126/science. 847460

Engel, George (1980) The clinical application of the biopsychosocial model. The American Journal of Psychiatry 137 (5), 535-543. https://doi.org/10.1176/ ajp.137.5.535

Frankenhaeuser, Beata (2014) Terveyssosiaalityön käyttämättömät mahdollisuudet psykiatrian ympäristössä. Teoksessa Anna Metteri, Satu Ylinen \& Heli Valokivi (toim.) Terveys ja sosiaalityö. Jyväskylä: PS-kustannus, 64-72.

Frost, Nick (2005) Professionalism, partnership and joined-up thinking: a research review of front-line working with children and families. Dartington: Research in Practice. http://niko.aides63.free.fr/ Documents/Doro/Dissert/Professionalism_partnership $\% 20$ and $\% 20$ joined $\% 20$ up\%20thinking.pdf. Luettu 30.9.2018.

Granfelt, Riitta (1993) Psykososiaalinen orientaatio sosiaalityössä. Teoksessa Harri Jokiranta, Synnöve Karvinen, Aila-Leena Matthies, Anneli Pohjola \& Riitta Granfelt (toim.) Monisärmäinen sosiaalityö Jyväskylä: Gummerus, 177-222.

Guest, Greg \& Namey, Emily \& McKenna, Kevin (2017). How many focus groups are enough? Building an evidence base for nonprobability sample sizes. Field methods 29 (1), 3-22. https://doi. org/10.1177/1525822X16639015

Gunningham, Joyce M. \& Booth, Robert A. (2008) Practice with children and their families: a specialty of clinical social work. Child an Adolescent Social Work Journal (25) 5, 347-365. https://doi. org/10.1007/s10560-008-0133-1

Gustafsson, Carina \& Öjehagen, Agneta \& Sandlund, Mikael \& Nyström, Marie \& Glad, Johan \& Cruce, Gunilla \& Jonsson,
Ann-Kristin \& Fredriksson Maja (2009) Effects of psychosocial interventions for people with intellectual disabilities and mental health problems. A survey of systematic reviews. Research on Social Work Practice 19 (3), 281-290. https:// doi.org/10.1177/1049731508329403

Hotari, Kaisa-Elina \& Metteri, Anna (2010) Sosiaalityöntekijöiden ja organisaatioiden välinen yhteistyö ja työnjako nuorten palveluissa. Pirkanmaan sairaanhoitopiirin julkaisusarja 4/2010, kehittämisprojektien loppuraportti. Tampere Pirkanmaan sairaanhoitopiirin kuntayhtymä.

Juhila, Kirsi (2006) Sosiaalityöntekijöinä ja asiakkaina: Sosiaalityön yhteiskunnalliset tehtävät ja paikat. Tampere:Vastapaino.

Kaminski, Jennifer W. \& Valle, Linda A. \& Filene, Jill H. \& Boyle, Cynthia L. (2008) "A meta-analytic review of components associated with parent training program effectiveness." Journal of Abnormal Child Psychology 36 (2), 567-589. https://doi. org/10.1007/s10802-007-9201-9

Kean, Jessica (2009) Mental illness and addictions: our responsibility to support the family. Aotearoa New Zeland Social Work 21 (3), 26-32. https://doi. org/10.11157/anzswj-vol21iss3id272

Kekoni, Taru \& Mönkkönen, Kaarina \& Hujala, Anneli \& Laulainen, Sanna \& Hirvonen, Jukka (2019) Moniammatillisuus käsitteinä ja määritteinä. Teoksessa Kaarina Mönkkönen, Taru Kekoni \& Aini Pehkonen (toim.) Moniammatillinen yhteistyö. Vaikuttava vuorovaikutus sosiaali- ja terveysalalla. Tallinna: Gaudeamus, 15-46.

Kerätär, Raija \& Taanila, Anja \& Härkäpää, Kristiina \& Ala-Mursula, Leena (2014) Sairauslähtöisestä työ- ja toimintakyvyn arvioinnista monialaiseen arviointimalliin. Lääketieteen aikakauskirja Duodecim 130 (5), 495-502.

Korpela, Rauni (2014) Terveyssosiaalityön asiantuntijuus ja kehittäminen. Teoksessa Anna Metteri, Satu Ylinen \& Heli Valokivi (toim.) Terveys ja sosiaalityö. Juva: Bookwell, 118-141.

Kuntaliitto (2017) Rajapinnoilta yhdyspintoihin. Kehittämisaloite kunnan ja maakunnan yhteistyöstä. Kuntaliiton verkkojulkaisu https://www.kuntaliitto. 
fi/julkaisut/2016/1794-rajapinnoiltayhdyspintoihin-kehittamisaloite-kunnan-ja-makunnan-yhteistyosta Luettu 9.1.2019.

Leinonen, Leena (2018) Sosiaalityön terapeuttinen asiantuntijuus psykiatrisessa erikoissairaanhoidossa. Teoksessa Tarja Juvonen, Jari Lindh, Anneli Pohjola \& Marjo Romakkaniemi (toim.) Sosiaalityön muuttuva asiantuntijuus. Sosiaalityön tutkimuksen vuosikirja. EU: Unipress, 134-153.

Leppälahti, Raija (2014) Asiakas- ja perhekeskeinen työkäytäntö perusterveydenhuollossa. Teoksessa Anna Metteri, Heli Valokivi \& Satu Ylinen (toim.) Terveys ja sosiaalityö. Jyväskylä: PS-Kustannus, 44-51.

Liamputtong, Pranee (2011) Focus group methodology and principles. London: Sage Publications. https://doi. org/10.4135/9781473957657

Mayring, Philipp (2004) Qualitative content analysis. Teoksessa Uwe Flick, Ernst von Kardoff \& Ines Steinke (toim.) A companion to qualitative research. London: Sage Publications.

McCrae, Niall \& Murray, Joanna \& Huxley, Peter \& Evans, Sherrill (2005) The research potential of mental-health social workers: a qualitative study of the views of senior mental-health service managers. British Journal of Social Work: 25 (1), 55-71. https://doi.org/10.1093/bjsw/ bch162

Muralidhar, Anvar Sadath V, D. \& Varambally, Shivarama (2012) Clinical social work perspective on case management in mental health. In-depth psychosocial analysis and intervention in a single case. Rajagiri Journal of Social Development 4 (1), 71-80.

Mäntyranta, Taina \& Kaila, Minna (2008) Fokusryhmähaastattelu laadullisen tutkimuksen menetelmänä lääketieteessä. Lääketieteellinen aikakauskirja Duodecim 124 (13), 1507-1513. http://www.ebmguidelines.com/xmedia/duo/duo97349. pdf. Luettu 29.1.2019.

Mönkkönen, Kaarina \& Leinonen, Leena \& Arajärvi, Miina \& Hovatta, Anna-Elina \& Tusa, Nina \& Salokangas, Katri (2019) Moniammatillisen vuorovaikutuksen tarkastelua. Teoksessa Kaarina Mönkkönen,
Taru Kekoni \& Aini Pehkonen (toim.) Moniammatillinen yhteistyö. Vaikuttava vuorovaikutus sosiaali- ja terveysalalla. Tallinna: Gaudeamus, 47-88.

Neergaard, Helle \& Leitch, Claire (2015) Handbook of qualitative research techniques and analysis on entrepreneurship. Cheltenham: Edward Elgar. https://doi. org $/ 10.4337 / 9781849809870$

Nikander, Pirjo (2010) Laadullisten aineistojen litterointi, kääntäminen ja validiteetti. Teoksessa Pirjo Nikander, Matti Hyvärinen \& Johanna Ruusuvuori (toim.) Haastattelun analyysi. Tampere: Vastapaino, 432-445.

Nurmi, Anna (2016) Sosiaalisen tilanteen arviointi. Käytäntötutkimus HYKS:n nuorisopsykiatrian klinikkaryhmässä tehtävästä sosiaalisen tilanteen arviointityöstä ja kehittämistarpeista. Helsingin yliopisto, valtiotieteellinen tiedekunta. http:// www.socca.fi/files/5940/Nuoren_sosiaalisen_tilanteen_arviointi_Kaytantotutkimus_HYKSn_nuorisopsykiatrian_klinikkaryhmassa_Anna_Nurmi_2016.pdf Luettu 19.1.2019.

Pehkonen, Aini \& Mönkkönen, Kaarina \& Kekoni, Taru (2019) Hoidon alkuarvioinnin tulkintakehykset mielenterveystyössä. Sosiaalilääketieteellinen aikakauslehti 56 (2), 102-113. https://doi. org/10.23990/sa.70181

Pirttijärvi, Mirja (2013) Merkintöjä marginaalissa. Terveyssosiaalityö aikuispsykiatriassa potilaan taloudellisen ja sosiaalisen selviytymisen edellytysten määrittelijänä. Jyväskylän yliopisto https://www.sosnet. fi/loader.aspx?id= c19841f7-2357-4f70b7ed-d91a2db1d194. Luettu 15.8.2019.

Ruusuvuori, Johanna \& Nikander, Pirjo \& Hyvärinen, Matti (2010) Haastattelun analyysin vaiheet. Teoksessa Pirjo Nikander, Matti Hyvärinen \& Johanna Ruusuvuori (toim.) Haastattelun analyysi. Tampere:Vastapaino, 9-36.

Rydenfält, Christofer \& Borell, Jonas \& Erlingsdottir, Gudbjörg (2018) What do doctors mean when they talk about teamwork? Possible implications for interprofessional care. Journal of interprofessional care 33 (6), 714-723. https:// doi.org/10.1080/13561820.2018.1538 943

Savolainen, Katri (2011) Sosiaalityö toivon 
luojana. Yhteisösuuntautunut toimintakulttuuri mielenterveyden edistämisessä. Teoksessa Petri T. Ruuskanen, Katri Savolainen \& Mari Suonio (toim.). Toivo sosiaalisessa. Toivoa luova toimintakulttuuri sosiaalityössä. Kuopio: UNIpress, 147-171.

Sim, Julius \& Waterfield, Jackie (2019) Focus group methodology: some ethical challenges, 53 (6), 3003-3022. https:// doi.org/10.1007/s11135-019-00914-5

Stemler, Steve (2001) Practical assessment, research \& evaluation. An overview of content analysis. Practical Assessment, Research and Evaluation 7 (17), 1-6.

Stenvall, Jari \& Virtanen, Petri (2012) Sosiaali- ja terveyspalveluiden uudistaminen. Kehittämisen mallit, toimintatavat ja periaatteet. Tallinna:Tietosanoma $\mathrm{Oy}$.

Terveyden ja hyvinvoinnin laitos (2019) Mitä toimintakyky on. https://thl.fi/fi/ web/toimintakyky/mita-toimintakykyon. Luettu 23.3.2020.

THL-raportti (2016) Valinnanvapaus ja integraatio palveluiden kehittämisen polttopisteessä, s 76-97. https://www.julkari.fi/bitstream/handle/10024/131276/ URN_ISBN_978-952-302-732-9. pdf?sequence $=1$. Luettu 11.11.2018.

Tiihonen, Eija \& Raikisto, Kaisu-Leena \& Ritsilä, Anu (2019) Monialainen palvelutarpeen arviointi terveyssosiaalityössä. Teoksessa Minna Zechner (toim.) Näkökulmia palvelutarpeen arviointiin. Seinäjoen ammattikorkeakoulu. Seinäjoen ammattikorkeakoulun julkaisusarja B, raportteja ja selvityksiä 144, 198-223.

Venkat, Pulla \& Abraham, P. Francis (2014) A strength approach to mental health. Teoksessa Francis Abraham (toim.) Social work in mental health: contexts and theories for practice. London: Sage, 126-143. https://doi. org/10.4135/9789351507864.n8

Vuori, Jaana (2001) Äidit, isät, ammattilaiset. Sukupuoli, toisto ja muunnelmat asiantuntijoiden kirjoituksissa Tampere: Tampere University Press. https://tampub.uta.fi/bitstream/hand1e/10024/67092/951-44-5065-5. pdf?sequence $=1$ Luettu 24.8.2018.

Väänänen, Riitta (2013) Perheen rakenteen, dynamiikan ja arvojen merkitys lapsen psyykkiselle hyvinvoinnille. Kuopio: Kopijyvä. http://epublications.uef. fi/pub/urn isbn 978-952-61-1271-8/ urn_isbn_978-952-61-1271-8.pdf Luettu 18.11.2018.

Weckroth, Antti (2007) Mitä merkitsee psykososiaalinen päihdehoidossa?Yhteiskuntapolitiikka 72 (4), 426-436. Helsinki:Julkari. https://www.julkari.fi/bitstream/ handle/10024/101216/074weckroth. pdf Luettu 19.1.2019.

(WHO) World Health Organization (2013) International Classification of Functioning, Disability and Health (ICF). https:// www.who.int/classifications/drafticfpracticalmanual2.pdf?ua $=1$. Luettu 16.3.2020. 